\title{
THE INFLUENCE OF INFORMATION TECHNOLOGY AND MANAGEMENT CONTROL SYSTEMS ON EMPLOYEE PERFORMANCE
}

\author{
Gun Gunawan Rachman ${ }^{*}$, Sita Nuraeni ${ }^{2}$ \\ Langlangbuana University, Indonesia*12 \\ gunawan.rachman74@gmail.com ${ }^{*}$, sitanuraeni31@gmail.com²
}

\begin{abstract}
This study aims to determine the influence of information technology and management control systems on employee performance at PT. Adira Dinamika Multifinance Tbk Baleendah Branch. The study was conducted on the employees of PT. Adira Dinamika Multifinance Tbk Baleendah Branch in the marketing division of 33 people. The research data is primary data and the analytical method used is descriptive verification method with quantitative approach and hypothesis testing and through data collection techniques with questionnaires. The statistical test tool used in this study is the Structural Equation Model (SEM) with Partial Least Square (PLS) estimation. The results of this study indicate that: 1) Information technology significantly influences employee performance 2) Management control system significantly influences employee performance
\end{abstract}

Keywords: Information Technology, Management Control Systems, Employee Performance.

\section{INTRODUCION}

Employee performance is a major problem in an organization because an organization or company will be able to achieve its goals or not, highly dependent on what is needed by its employees. It is employees who will determine organizational resources that can contribute optimally or not support the achievement of organizational goals. Whatever strategy is chosen by the organization in running its business, the chosen priority strategy chosen is differentiation or service business, then no company has a central position, they are determinants of the success of the business being run (Suparyadi 2015: 300). Furthermore Puspitayanti (2015) claims information technology for companies is an important requirement. The right information technology information will make the company have a competitive advantage. Information technology will be increasingly opened up for companies to develop and expand their businesses. Then Sutabri (2014) added implicitly and explicitly, IT does not only discuss computer technology, but complements communication technology. In other words, what is called information technology is a combination of computer technology and communication technology. Management control system in the system used by management to build the organization's future. To build the organization's future, it needs to be determined in advance and in business the organization will be needed. The answer to that question is the mission of the organization. Thus the organizational mission is the path chosen to bring the organization to realize the future (Mulyadi, 2004). Information Technology is a technology used to process data, including processing, obtaining, compiling, storing, manipulating data in various ways to produce quality information, namely information that is relevant, accurate and timely, which is used for personal, business, and administration and is the information requested to make decisions. Technology that uses computers as the main device for processing data into useful information (Taufiq 2018). 
$\begin{array}{llr} & \text { Management control system is a } \\ \text { system consisting of several } & \text { interconnected systems, namely }\end{array}$ programming, budgeting, accountability, and performance as well as a delegation of authority systems to assist management in several organizations or companies to get assistance in relation to an efficient and effective development strategy (Sukarno 2018). The performance of employees or employees in a certain period is the work of employees during a certain period compared to various standards, for example, targets, targets or criteria that have been predetermined and agreed upon together (Salih 2018: 57).

Hypothesis

Based on the above framework the authors hypothesize that: $\mathrm{H} 1$ : Information Technology affects employee performance. H2: Management control systems affect employee performance.

\section{METHODS}

The objects examined were information technology, management control systems, and employee performance at PT. Adira Dinamika Multifinance Tbk Baleendah Branch. Measurement of these variables, measured by measurement instruments in the form of a questionnaire (item statement) that is closed and given the opportunity to be able to answer openly and use the scores. Operationalization of Variables Variables are constructs whose properties have been given a number (quantitative) or can also be interpreted as variables are concepts that have a variety of values, in the form of quantitative or qualitative that can change in value (Siregar, 2016). In this study, Information Technology and Management Control Systems are Independent Variables, while Employee Performance is Dependent Variables.

\section{Population}

The population in this study were all employees of PT. Adira Dinamika Multifinance Tbk Baleendah Branch with a sample of 33 employees in the marketing division.

Sampling Method

The sampling method, according to Sugiyono (2013) says that the sample is part of the number and characteristics possessed by the population. For this reason, samples taken from the population must be truly representative. According to Hair et al (2014: 20), the minimum sample size for SEM-PLS can be determined by

\section{Rule of Thumb}

The minimum sample size study using the rule of thumb is ten times the number of arrow directions that points to the latent variable of the PLS pathway model (Hair et al, 2014)

\section{Power Analysis}

Determination of a minimum sample size using the power analysis method is also based on the part of the model with the most directional arrows. Furthermore Hair et al (2014) recommend some minimum sample sizes that can be taken for SEM-PLS with various significant levels and $R 2$. So in this study using power analysis at a significant level of $5 \%$ and $R 2=0.5 \%$, the sample taken by 38 people. Data Collection Procedure Data sources used are: 1. Primary data sources are data sources obtained directly from the subject or object. 2. Secondary data sources are data sources that are not directly obtained to the data collector because they are in the form of documents. So that in research using Power Analysis at a significance level of $5 \%$ and $\mathrm{R}^{2}=0.25$ a minimum sample of 33 can be taken.

Data Collection Procedure Data sources used are:

Primary data sources are data sources obtained directly from subjects or objects. Secondary data sources are data sources that are not directly 
obtained to the data collector because they are in the form of documents

\section{Validity test}

Validity is the extent to which a measuring instrument is able to measure what you want to measure (valid measure if it succesfully measures the phenomenon) (Siregar, 2016). Pearson Product Moment correlation analysis technique was used in this study. Its use is to determine the degree of relationship and contribution of the independent variable (independent) with the dependent variable (dependent) (Natawira and Riduwan, 2010)

\section{Reliability Test}

According to Sujarweni (2015) the reliability test is a measure of the stability and consistency of respondents in answering matters related to the constructs of questions which are dimensions of a variable and are arranged in the form of questionnaires.

\section{RESULTS AND DISCUSSION}

Descriptive Analysis Results Descriptive method of problem-solving procedures in this method is by describing the object of research at the present situation based on the facts as they are, then analyzed and interpreted, the form is in the form of surveys and study studies (Siregar, 2016).

$$
\text { Total Score }=\frac{\text { Actual Score }}{\text { Ideal Score }} \times 100 \%
$$

Table 1. Guidelines for the Categorization of Respondents' Average Score Responses

\begin{tabular}{ll}
\hline \multicolumn{1}{c}{ Category Response } & \multicolumn{1}{c}{ Catergory } \\
\hline $5.00-4.21$ & Very Good / Very High / Very Adequate / Always \\
$4.20-3.41$ & Good / High / Sufficient / Often \\
$3.40-2.61$ & Good Enough / Fair Enough / Occasionally / Fairly \\
& Agree \\
$2.60-1.81$ & Poor / Inadequate / Low / Rare \\
$1.80-1.00$ & Not Good / Inadequate / Very Low / Never \\
\hline
\end{tabular}

Source: SEM PLS

\section{Descriptive Analysis of Information Technology}

Information technology variables are measured through 6 dimensions and operated into 8 related indicators Based on research conducted on information technology, it can be seen that the results of the calculation of the total score and the mean score (average) value of the information technology variable can be concluded that the information technology variable is categorized well with a score of 3.84 . Grand mean 3.84 or equivalent to $76.8 \%$, which means information technology at PT. Adira Dinamika Multifinance Tbk Baleendah Branch has been running well and accordingly.
Judging from the assessment of indicators by respondents that IT has been carried out in accordance with procedures and functions. When compared with the ideal score $(100 \%)$, IT still has obstacles. GAP between the ideal score and the actual score of $23.2 \%$, to minimize this GAP, it is necessary to control and improve performance on information technology in the company so that any deficiencies in this IT variable can be improved so as to achieve an ideal score in the company that is $100 \%$ or can be interpreted as all respondents can answer the score at number 5 . 


\section{Descriptive Analysis of Management Control Systems}

The Management Control System variable is measured through 4 dimensions and operated into 6 related indicators. Based on research conducted on management control systems can be seen that the results of the calculation of the total score and the mean score (average) value of the variable management control system at PT. Adira Dinamika Multifinance Tbk Baleendah Branch can be categorized well with a score of 3.68. Grand mean 3.68 or equivalent to $73.6 \%$, which means the management control system at PT. Adira Dinamika Multifinance Tbk Baleendah Branch has been running well and accordingly. PT. Adira Dinamika Multifinance Tbk Baleendah Branch runs the dimensions of the management control system starting from strategic planning on the job, good budget preparation within the company, good implementation and in accordance with existing procedures, and also evaluating performance well. When compared with the ideal score $(100 \%)$ the management control system still has a gap of $26.4 \%$, this gap should be eliminated and expected to be reduced in order to achieve the ideal conditions expected by the management control system in PT. Adira Dinamika Multifinance Tbk Baleendah Branch so that it can reach the opimal point in the management control system. With the meaning all respondents can answer the score at number 5 .

\section{Descriptive Analysis of Employee Performance}

Employee Performance

Variables are measured through 6 dimensions and operate into 9 related indicators. Based on research conducted on employee performance can be seen that the results of the calculation of the total score and the mean score (average) value of employee performance variables can be concluded that the employee performance variables are categorized well with a score of 3.63 Grand mean 3.63 is equivalent to $72.6 \%$, which means the performance of employees at PT. Adira Dinamika Multifinance Tbk Baleendah Branch has been running well and accordingly. PT. Adira Dinamika Multifinance Tbk Baleendah Branch runs the existing dimensions in employee performance. When compared with the ideal score $(100 \%)$, employee performance still leaves a gap of $27.4 \%$, this gap should be eliminated and expected to be reduced in order to achieve the ideal conditions expected by employee performance at PT. Adira Dinamika Multifinance Tbk Baleendah Branch so that it can reach the point of opitmal. With the meaning all respondents can answer the score at number 5 . Analysis of the Effects of Information Technology and Management Control Systems on Employee Performance The analysis that is relevant to the purpose of the research is to obtain the results of a study of the models offered in overcoming problems in employee performance, then testing the hypothesis and looking for the influence of information technology and management control systems on employee performance. In structural equation modeling (PLS) there are two types of models that are formed, namely the measurement model and the structural model. The measurement model explains the proportion of variance of each manifest variable (indicator) which can be explained in latent variables. Through the measurement model, it will be known which indicator is more dominant in the formation of latent variables. After the measurement model of each latent variable is described, a structural model will be described that will examine the effect of each independent latent variable (exogeneous latent variable) on the endogenous latent variable. The measurement model is used as 
goodness af fit for the outer model. Where in this model fit test is explained both convergent validity and discriminant validity, convergent validity in the form of a loading factor that explains the proportion of variance of each manifest variable (dimensions / indicators) which can be explained in latent variables. Through the measurement model, it will be known which indicators are more dominant in reflecting latent variables. Dimensions which have a loading factor of less than 0.5 should be excluded from the model. Besides that, a greater $t$-value is obtained for each manifest variable. Where if tvalue is greater than 1.96 it means that the manifest variable reflects well on the latent variable. For discriminant validity we know the average variance extracted (AVE), and composite reliability (CR) as a test of the match of manifest variables that are able to reflect the latent variables. Good composite composition is giving a value greater than $0.7(C R>0.7)$ while a good average extracted variance (AVE) is giving a value greater than 0.5 (AVE> 0.5).

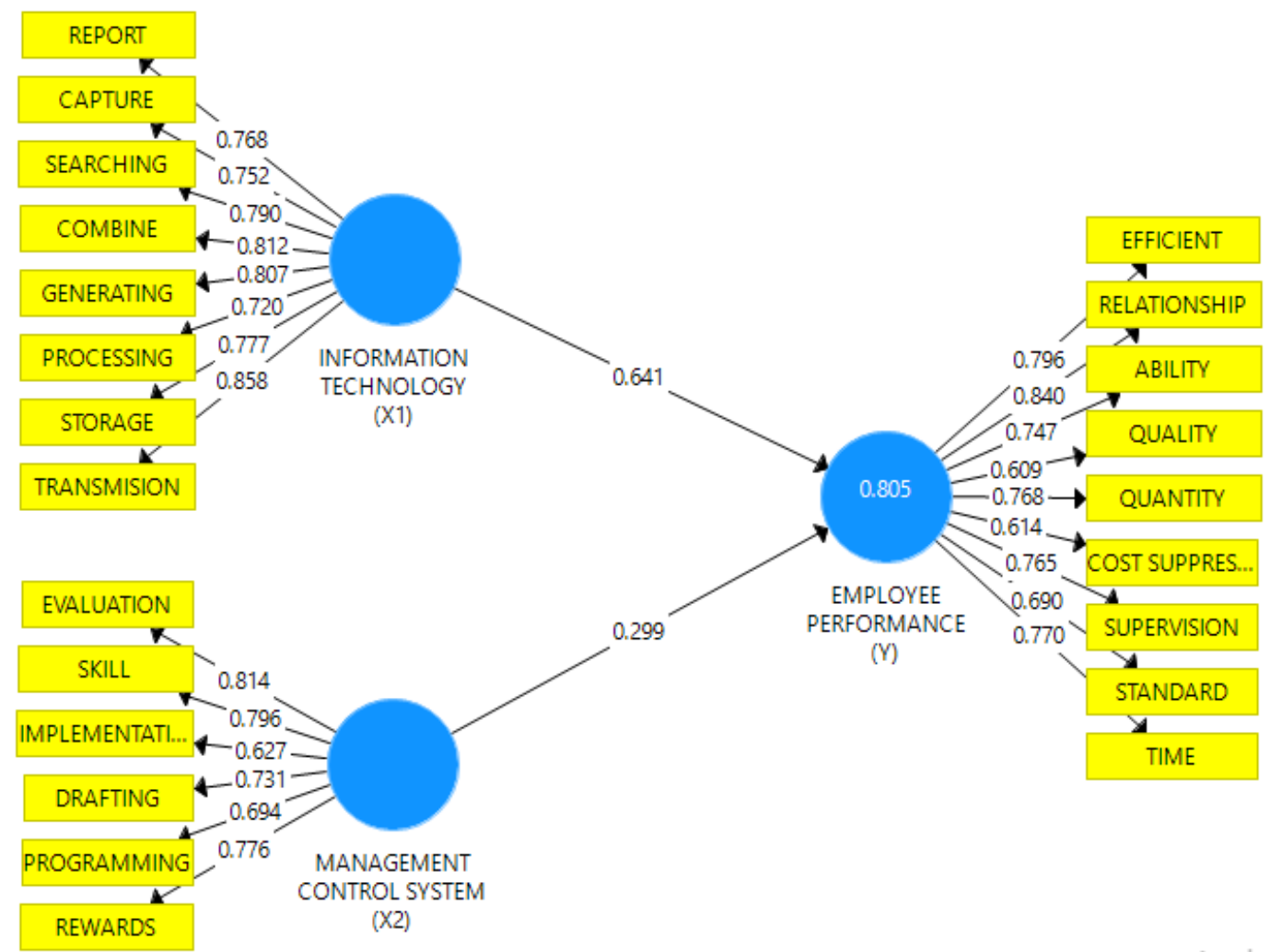

Figure 1. Load factor path diagram

Source: SEM PLS

Specifications for Information Technology Measurement Models Information technology variables are measured using 6 dimensions that are operated into 8 indicators, namely capture, process, combine, produce, accurate, save, search, retival, transmission. This is a reflective dimension, the estimated results of the parameters of the measurement model of this variable are shown in Figure 4.3 


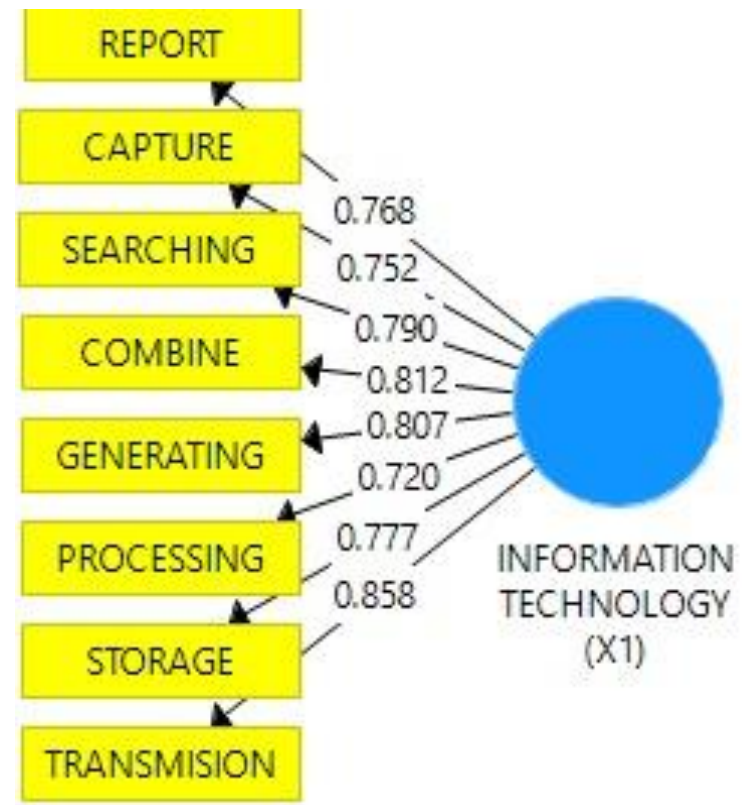

Figure 2. Information Technology Path Diagram Source: SEM PLS

Outer loading and reflective constructs of information technology measurement are all worth above 0.50 . The capture dimension has a loading value of 0.752 , above the threshold of 0.50 and is significant $(p=0,000)$ at $5 \%$ significance level. This dimension has a reliability indicator $(0.750)$. Then the processing / processing dimension has a loading value of 0.720 , above the threshold of 0.50 and significant $(\mathrm{p}=$ 0,000 ) at a $5 \%$ level. This dimension has a reliability indicator (0.730). The merging dimension has a loading value of 0.812 , above the threshold of 0.50 and is significant $(p=0,000)$ at the $5 \%$ level. This dimension has a reliability indicator (0.816). The Generating dimension has a loading value of 0.807 , above the threshold of 0.50 and is significant $(p=0,000)$. This dimension has a reliability indicator $(0.807)$. Then the dimensions of the report have a loading value of 0.768 , above the threshold of 0.50 and significant $(p=$ 0,000 ) at the $5 \%$ significance level. This dimension has a reliability indicator (0.764). The saving / strorage dimension has a loading value of 0.777 , above the threshold of 0.50 and is significant $(p=$
0,000 ) at a $5 \%$ level, this dimension has a reliability indicator $(0.787)$. Then the Retrieval Dimension has a loading value of 0.790 , above the threshold of 0.50 and is significant $(p=0,000)$ at $5 \%$ significance level, this dimension has a reliability indicator $(0.797)$ and the Transmission Dimension has a loading value of 0.858 , above the threshold limit of 0.50 and significant $(p=0,000)$ at $5 \%$ significance level, this dimension has a reliability indicator (0.861).

The AVE value of 0.619 is above the average value of 0.50 . Likewise, the composite reliability value of the construct value above seems to have a value of 0.928 above the minimum value of 0.80 . This means that this dimension has been declared very good. Discriminant validity tested through cross loading (table 4.23) shows that the loading facor on the Transmission dimension is higher than the other dimensions, thus providing evidence for construct discriminant validity found in Information Technology. Specifications of Management Control System Measurement Model The management control system 
variable which is measured using 4 units is operated into 6 indicators namely the dimensions of strategic planning, expertise, budgeting dimensions, implementation dimensions, work evaluation dimensions and rewards. This dimension is a reflective dimension, the estimated results of the measurement parameters of this variable model are shown in Figure 4.4

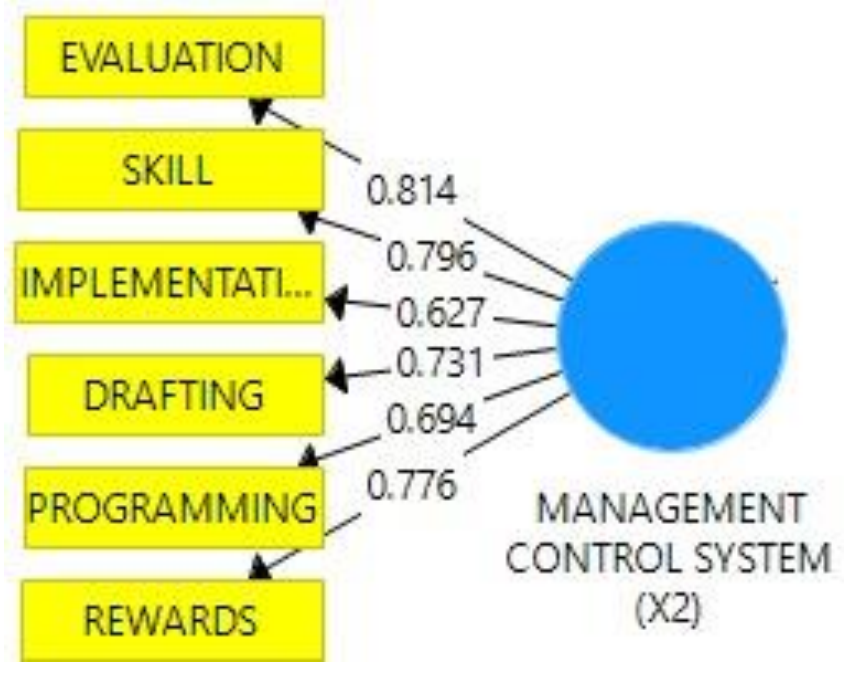

Figure 3. Management Control System Path Chart Source: SEM PLS

Outer loading and reflective constructs of management control system measurements are all worth above 0.50. The Strategic Planning dimension has a loading value of 0.694 above the threshold of 0.50 and is significant $(p=0,000)$ at the $5 \%$ level. This dimension has a reliability indicator (0.698). Then the dimension of expertise has a loading value of 0.796 above the threshold of 0.50 and is significant $(p=$ 0,000 ) at the $5 \%$ significance level. This dimension has a reliability indicator (0.979). Dimension The preparation of the budget has a loading value of 0.731 above the 0.50 threshold and is significant $(p=0,000)$. This dimension has a reliability indicator $(0.728)$. The implementation dimension has a loading value of 0.627 above the threshold of 0.50 and is significant $(p=0,000)$ at $5 \%$ significance level, this dimension has a reliability indicator (0.610). Then the work evaluation dimension has a loading value of 0.814 above the 0.50 threshold and is significant $(p=0,000)$ at $5 \%$ significance level, this dimension has a reliability indicator $(0.803)$ and the rewards dimension has a loading value of 0.776 above the 0.50 threshold and is significant $(p=0,000)$ at the $5 \%$ level, this dimension has a reliability indicator (0.780).

The AVE value of 0.551 is above the average value of 0.50 . Likewise, the composite reliability value of the construct value above seems to have a value of 0.880 above the minimum value of 0.80 . This means that this dimension has been declared very good. Discriminant validity tested through cross loading (table 4.25) shows that the dimension of expertise is higher than the other dimensions, thus providing evidence for construct discriminant validity in the management control system.

\section{Employee Measurement Model Specifications}

Performance

Submitted: September 29, 2020; Accepted: December 05, 2020;

Published: December 16, 2020; Website: http://journalfeb.unla.ac.id/index.php/jasa 


Employee performance
variables are measured using 6
dimensions operated into 9 indicators
namely, dimensions of quality,
standards, capabilities, quantity
dimensions, time dimensions, cost
emphasis dimensions, dimensions of

supervision, efficiency and dimensions of relationships between employees. This dimension is a reflective dimension, the estimated results of the measurement parameters of this variable model are shown in Figure 4.5

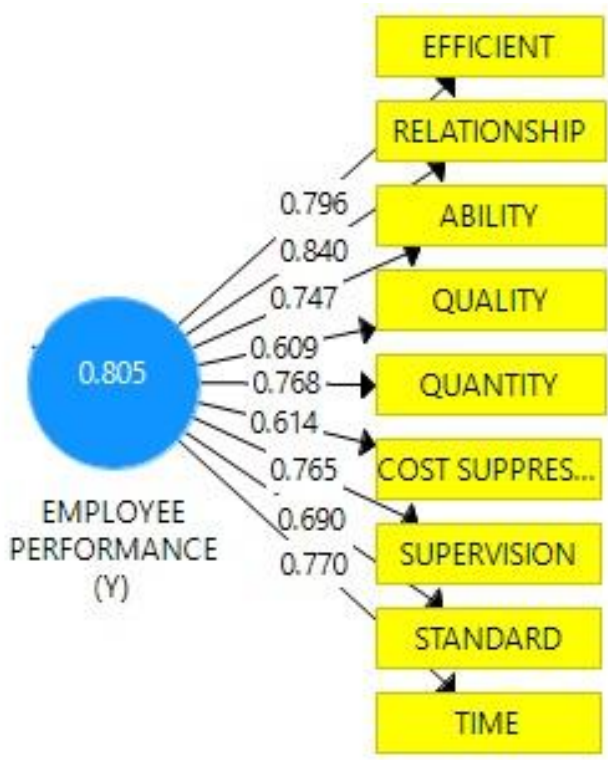

Figure 4. Employee Performance Path Chart Source: SEM PLS

Outer loading and reflective constructs of measurement of the quality of management accounting information systems are all worth above 0.50 . The quality dimension has a loading value of 0.609 above the 0.50 threshold and is significant $(p=0,000)$ at the $5 \%$ significance level. This dimension has a reliability indicator (0.606). Then the standard dimensions have a loading value of 0.690 above the 0.50 threshold and are significant $(p=0,000)$ at the $5 \%$ significance level. This dimension has a reliability indicator (0.682). The ability dimension has a loading value of 0.747 above the threshold of 0.50 and is significant $(p=0,000)$. This dimension has a reliability indicator $(0.749)$. The quantity dimension has a loading value of 0.768 above the 0.50 threshold and is significant $(p=0,000)$ at the $5 \%$ level, this dimension has a reliability indicator (0.775). Then the time dimension has a loading value of 0.770 above the threshold of 0.50 and is significant $(p=$ 0,000 ) at a $5 \%$ level of significance, this dimension has an indicator of reliability (0.771). The cost emphasis dimension has a loading value of 0.614 above the 0.50 threshold and is significant $(\mathrm{p}=$ 0,000 ) at $5 \%$ significance level, this dimension has a reliability indicator (0.612). The supervision dimension has a loading value of 0.765 above the threshold of 0.50 and is significant $(p=$ 0,000 ) at $5 \%$ significance level, this dimension has a reliability indicator (0.763). The efficient dimension has a loading value of 0.796 above the threshold of 0.50 and is significant $(p=$ 0,000 ) at the $5 \%$ level, this dimension has a reliability indicator (0.804). Then the last dimension of relations between employees has a loading value of 0.840 above the threshold of 0.50 and is significant $(p=0,000)$ at the $5 \%$ level, 
this dimension has a reliability indicator (0.847). The AVE value of 0.543 is above the average value of 0.50 . Likewise, the composite reliability value of the construct value above seems to have a value of 0.914 above the minimum value of 0.80 . This means that this dimension has been declared very good. Discriminant validity tested through cross loading (table 4.27) shows that the dimensions of employee relations are higher compared to other dimensions, thus providing evidence for construct discriminant validity found in employee performance.

\section{Structural Model Analysis Collinearity Testing}

The structural model explains the causality relationship between research variables. Structural model analysis is related to testing the research hypothesis. Before conducting the analysis, it is necessary to test the structural model for collinearity. The reason is that the estimation of path coefficients in the structural model is based on the OLS regression of each endogenous latent variable for the constructs related to it. In multiple regression, the estimated path coefficient will be biased if there is a significant degree of collinearity among the constructs of the predictor. To evaluate collinesity, a measure of the variance of inflation factor (VIF) is used, in the context of PLS-SEM, a tolerance value of 0.20 or less than a VIP value of 5 or more indicates a collinearity problem (Hair et at, 2014: 186). Evaluation of Structural Models The structural model represents the relationship between latent variables. In this study the structural model is related to two research hypotheses which hint at the causality relationship between latent variables. The structural model in this study involves one exogenous latent variable (management control system and leadership style) and one endogenous latent variable (employee performance). The results of the calculation of standardized path coefficients for structural models of the influence of management control systems and leadership styles on employee performance are shown in Figure 4.6 below.

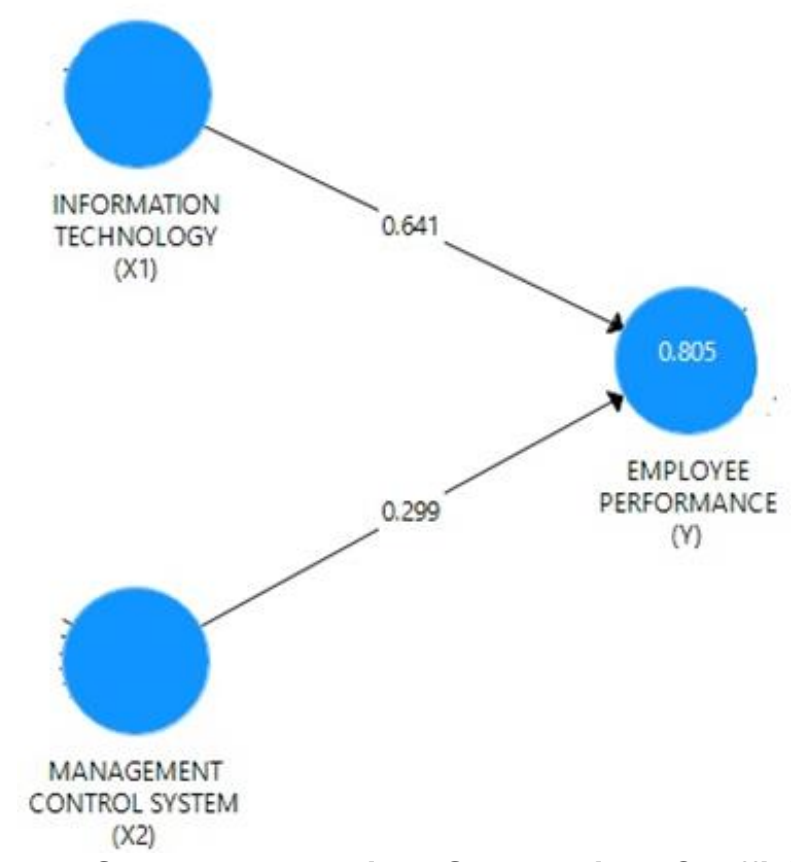

Figure 5. Structural Modelized Standardized Coefficients Source: SEM PLS 


\section{Hypothesis test}

Statistical Hypothesis 1

$\mathrm{H} 0: \mathrm{Y} 11=0$ Implementation of information technology has no effect on employee performance. $\mathrm{H} 1$ : $\mathrm{Y} 11 \neq 0$ Implementation of information technology has a significant effect on employee performance

Statistical Hypothesis 2

$\mathrm{H} 0: \mathrm{Y} 12=0$ Implementation of management control systems does not affect employee performance. $\mathrm{H} 1: \quad \mathrm{Y} 12 \neq 0$ Implementation of management control systems affect employee performance To test this hypothesis the t-student test statistic like what was explained in chapter 3 . The test criterion is $\mathrm{HO}$ is rejected if the $p$-value is smaller than $\alpha$, with $\alpha=0.05$. The test results are summarized in the table below:

Table 2. Hypothesis Testing Results

\begin{tabular}{lllll}
\hline Statistical & Path & t- & $p$ - & Information \\
Hypothesis & Coefficient & Count & Value &
\end{tabular}

\begin{tabular}{lllll}
\hline $\mathrm{H}_{0}: \mathrm{Y}_{11}=0$ & 0,641 & 5,959 & 0,000 & $\mathrm{H}_{0}$ rejected \\
$\mathrm{H}_{0}: \mathrm{Y}_{11} \neq 0$ & & & & \\
$\mathrm{H}_{0}: \mathrm{Y}_{12}=0$ & 0,299 & 2,640 & 0,009 & $\mathrm{H}_{0}$ rejected \\
$\mathrm{H}_{0}: \mathrm{Y}_{12} \neq 0$ & & & & \\
\hline
\end{tabular}

Source: SEM PLS

\section{Hypothesis Testing Results 1}

Based on the table above, it can be seen that the t-count value of information technology variables (5.959) is greater than tcritical (1.96) which means that the results of hypothesis 1 are $\mathrm{H} 0$ rejected, then the statistical conclusion is that information technology has a significant effect on employee performance.

\section{Hypothesis Testing Results 2}

Based on the above table, it can be seen that the $t$-value of the management control system variable $(2,640)$ is greater than tcritical $(1.96)$ which means that the results of hypothesis 1 are $\mathrm{H} 0$ rejected, then the statistical conclusion is that the management control system significantly influences employee performance. Based on the results of calculations performed, the f2 value obtained from information technology is 0.770 because the f2 value is above 0.35 (Limitation of the effect size of large size) so it can be stated the effect size for the influence of information technology on employee performance that is large or large. While the results of the calculation of the $f 2$ value of the management control system amounted to 0.167 because the f2 value above 0.15 (limiting the value of the effect size of medium or medium) then it can be stated the effect size for the influence of the management control system on employee performance that is medium or moderate.

Another measure used to evaluate structural models is the coefficient of employee performance (R2). Presenting the relationship between information technology variables and management control systems as predictors and endogenous latent variables of employee performance gives the calculation result $\mathrm{R} 2=0.805$. So it can be concluded that $80.5 \%$ variance in employee performance variables is explained by the information technology variable and management control system, the rest is explained by other factors.

\section{Discussion \\ This section discusses the results of empirical tests for each}


problem statement and hypothesis. Based on the results of descriptive analysis and verification analysis which is then compared with the theories and results of previous studies. In addition to using the results of the questionnaire answers, in responding to the problems in this study, open information from the responses of respondents is needed in addition to supporting the suggestions that will be submitted as a solution to the problem in this study. This research is a testing (confirmation) theory that is used to build hypotheses. For this research the hypothesis is built on the theory of logical explanations and the results of previous studies that are tested with facts that exist empirically. The theoretical framework used by researchers as a conceptual model of the relationship between the factors identified to provide solutions to problem solving on managerial performance has been statistically tested both for the outer model (the association of manifest variables with other variables) and for the inner model (the relationship between exogenous variables and endogenous variables). The results of the testing of the model fit for the outer model specified based on the operationalization of the variables by considering the reflective orientation show convergent validity, that is, the correlation between item scores and construck scores shows outer loading $0.5-0.9$. This means that the variable has a good ability to reflect the latent variable. And shows the tcount above tcritis that is equal to 1.96 . For discriminant validity, that is, the validity of the constructs formed is seen based on the value of AVE (average variance extracted) all above the minimum value of 0.50 . Furthermore, the evaluation of the measurement model of the model (outer model) can also be seen from the value of composity reliability (CR) where the $C R$ value is greater than 0.70 and the results are as expected. The greater the value of God (Goodness of Fit), the more fit a model is. The results of testing the suitability of the model for the inner model, the hypothesis is accepted with a tcount above the tcritical value of 1.96 . The hypothesis has been tested and supports the theory so that if the same hypothesis with different units of analysis and samples is consistent, the results from time to time and from testing to theory testing will persist until other theories shift, so that research can build and develop theories.

\section{Influence of Information Technology on Employee Performance}

Based on the results of research that has been done, that information technology on employee performance of 0.641 and included in the large category. This coefficient shows that the employee performance variable is explained by information technology reflected by capturing, processing, combining, generating, accurate, storing, retrieval, transmitting. Viewed from the loading factor path diagram, the capture dimension has a loading factor of 0.752 , whereas for the processing dimension has a loading factor of 0.720 , combines has a loading factor of 0.812 , produces has a loading factor of 0.807 , and storage has loading factor of 0.777 , then for the retrieval dimension has a loading factor of 0.790 and the last transmission dimension has a loading factor of 0.858 which contributes greatly compared to other dimensions. With this, information technology provides a change in employee performance if the information technology can help in providing information as decision making in a condition effectively and efficiently. And information that is accurate, precise and has a good capacity in terms of storing data. Research findings on information technology which shows that information technology is in the good category, but not perfect. This is due to the following: Capture (capture) has shown that the accuracy of the data and the meaning of data at PT. Adira Dinamika Multifinance Tbk Baleendah Branch is already good, 
but not completely perfect, due to technical obstacles in its implementation such as connectivity and hardware constraints that can reduce the accuracy of the data and the meaning of the data. Because information technology is very dependent on the data speed and connectivity available. Generating has shown that organizing information into useful forms such as in the form of tables or graphs at PT. Adira Dinamika Multifinance Tbk Baleendah Branch is already good but not completely perfect, because some employees do not have the ability to process information. So there is an error in inputting data that causes results are not optimal. Thus the results of the study showed that at PT. Adira Dinamika Multifinance Tbk Baleendah Branch on information technology significantly affects employee performance, so if the higher or lower information technology is used it will increase or lower employee performance.

\section{Effect of Management Control Systems on Employee Performance}

Based on the results of research that has been done, that information technology on employee performance of 0.299 and included in the medium or medium category. This coefficient shows that the variable performance of employees is explained by the dimensions that exist in the management control system. Based on the results of the loading factor, it can be seen that the expertise dimension has a higher yield than the other dimensions, which is 0.979 , which indicates that PT. Adira Dinamika Multifinance Tbk Baleendah Branch places employees according to their expertise. With this, the expertise dimension will provide a change in the performance of employees at PT. Adira Dinamika Multifinance Tbk Baleendah Branch. The above research findings regarding the management control system which shows that the management control system is in the good category, but not perfect. This is due to the following: Strategic planning shows that the suitability of strategic planning with the programs produced at PT. Adira Dinamika Multifinance Tbk Baleendah Branch is already good but not perfect, this is due to inadequate allocation of resources ie there are still employees who work not in accordance with their expertise. In addition, some employees do not have a sense of responsibility in the strategy, meaning that employees only implement the strategy if it is personal benefit. So that between strategic planning and implementation has not run optimally. Budgeting at PT. Adira Dinamika Multifinance Tbk Baleendah Branch is already good but not perfect, this is due to the decline in branch sales, employee reductions and the budget set exceeds the costs incurred. So that there are still company strategies and plans that have not been fully achieved. Job evaluation shows that there is still a lack of evaluation of the work results of employees at PT. Adira Dinamika Multifinance Tbk Baleendah Branch, which has an impact on the company's work report. This is caused by a distortion between the Marketing Head $(\mathrm{MH})$ and his subordinates (CMO). As in job evaluations, $\mathrm{MH}$ often covers the mistakes of subordinates before work reports are made which will be submitted to central management. In addition, it is caused by the frequent employees working in the field so that checks / assessments are not regularly conducted.Thus the results of the study showed that at PT. Adira Dinamika Multifinance Tbk Baleendah Branch in the management control system significantly affects employee performance, then if the higher or lower management control system is used it will increase or lower employee performance.

\section{CONCLUSION}

Based on the phenomena, problem formulation, hypotheses and 
research results, the conclusions of this study are as follows: Information technology affects the performance of employees at PT. Adira Dinamika Multifinance Tbk Baleendah Branch. Information technology at PT. Adira Dinamika Multifinance Tbk Baleendah Branch has been running well, but not yet fully optimal. This was revealed because the dimensions of capture (capture) and generate (generating) have not fully supported the nets of information technology or have not gone perfectly at PT. Adira Dinamika Multifinance Tbk Baleendah Branch. Management control systems affect employee performance. However, the management control system is not yet fully ideal, because several indicators of the management control system are strategic planning, budgeting and work evaluation although it is said to be good but its implementation has not been carried out perfectly.

\section{REFERENCES}

Hair, J. F., M, C. R., \& Marko, S. (2017). A Primer On Partial Least Squares Struktural Equation Modelling (PLS-SEM). London: SAGE Publication Inc.
Mulyadi, Setyawan Jhony. (2007). Sistem Perencanaan dan Pengendalian Manajemen. Jakarta: Salemba Empat.

Shaleh, M. (2018). Komitmen Organisasi terhadap Kinerja Pegawai. Makasar: Aksara Timur

Siregar, S. (2016). Statistika Deskriptif untuk Penelitian . Jakarta: PT Rajagrafindo Persada.

Sukarno, Edy. (2000). Sistem Pengendalian Manajemen. Jakarta: Gramedia Pustaka Utama.

Sumarsan, T. (2013). Sistem Pengendalian Manajemen (Konsep, Aplikasi, dan Pengukuran Kinerja). Jakarta Barat: PT Indeks.

Suparyadi. (2015). Manajemen Sumberdaya Manusia. Yogyakarta: CV Andi Offset.

Taufiq, Rohmat. 2018. "Pengantar Sistem Informasi" Jakarta: Mitra Wacana Media.

Puspitayanti, N. E.(2015). Pengaruh Locus of Control dan Kemampuan Mengoperasikan Teknologi Informasi terhadap Kinerja Karyawan pada PT Pegadaian (PERSERO) Denpasar ahun 2015. 05(01). 